\title{
DEVELOPMENT OF A COMPETITIVE AIR-TRANSPORT MARKET IN VIETNAM: ISSUES AND EXPERIENCE FOR COUNTRIES IN TRANSITION
}

\author{
HOAI HUAN PHAM* \\ Department of Commercial Law, Ho Chi Minh City University of Law \\ Email:phhuan@hcmulaw.edu.vn
}

\begin{abstract}
In the last decade, the development of the air-transport market in Vietnam has been remarkable. The country has become one of the world's fastest growing air-transport market after adopting the Law of Civil Aviation in 2006. However, there are various issues that limit fair competition in the domestic air-transport market. By analysing the conditions of access to resources in the sector, this paper aims to identify factors that directly affect competition in the airline business in Vietnam and propose some policy changes to improve competitiveness in the air-transport market, which might be of relevance to other countries in transition.
\end{abstract}

Keywords: air-transport, airlines, competition, Vietnam, state-owned enterprises, low-costairlines, margin squeeze

\section{OVERVIEW OF VIETNAM'S AIR-TRANSPORT MARKET}

Air transportation services have always been seen by countries as having an inherently strategic role. From the earliest days, a century ago, airlines were seen as a means of providing high-speed mail delivery services, and subsequently medium and long-haul passenger and high-value cargo transportation. Nowadays, technology allows the carriage of much larger cargo pay-loads in a more reliable and cost-efficient way. These strategic functions were the justification to pursue internal national policies of social, political, and economic integration within most countries and to promote 'national champions' in the international air transport market. As such, air-transport was traditionally a highly regulated and protected environment with the intention of it being used as a lever for larger political and economic objectives. ${ }^{1}$

Like most countries in transition, the aviation market of Vietnam has long been the domain of the State. The State controlled the air

\footnotetext{
* He is currently teaching at the Ho Chi Minh City University of Law with nearly 15 years' experience teaching graduate and undergraduate business law courses, including Corporate Governance and Antitrust Law; He is also an active scholar. His paper was presented at the Asian Competition Forum. He was an ASEAN scholar at the Tallinn Law School, TTU, Estonia. As a legal practitioner, he has advised a considerable amount of M\&A transactions; This research has received funding from the European Union's Horizon 2020 research and innovation program under the Marie Skłodowska-Curie grant agreement No 734712.

Button K. (2008), The Impacts of Globalisation on International Air Transport Activity: Past trends and future perspectives, Conference Paper, OECD/ITF Global Forum on Transport and Environment in a Globalising World, held 10-12 November 2008 in Guadalajara, Mexico, pp. 6-7.
} 
transportation sector through the establishment of a monopolized aviation market, in which the State acted as the sole investor for the entire sector - owning the air-transport enterprises as well as dictating the provision and operation of the support services linked to air transportation. With the advent of trade liberalization policies following the Doi Moi reforms in the late 1980s, the Vietnamese aviation market began to open up to private airline companies. The Law of Civil Aviation of Vietnam in 2006 marked a significant change in aviation regulations by allowing private parties, including Vietnamese organizations and individuals, to establish and operate airline companies. Foreign invested airlines, in the form of a joint venture enterprise, in which foreign investors' equity cap was limited to $49 \%$ of the capital of the joint venture, were also permitted by this law. The deregulation in the aviation sector has caused many changes in Vietnam's aviation market, which include the entry of private airtransport enterprises, the diversification of air-related service providers, and an increase in the variability of passenger fares across the market.

The deregulation policy has contributed greatly to the development of the aviation sector in Vietnam in the last decade. Vietnam is viewed as one of the world's fastest growing aviation markets. According to statistics prepared by Airports Corporation of Vietnam (ACV), for the period of 2006-2016 the average CAGR per annum growth rate is $17.4 \% .^{2}$ In 2016 alone, the total volume of passengers was estimated to be approximately 81 million, a $29 \%$ increase over the same period in $2015 .^{3}$ The International Air Transport Association (IATA) anticipates that in the next five years Vietnam will be the fifth fastest-growing aviation market in the world, averaging nearly $14 \%$ and will reach 150 million passengers by $2035 .{ }^{4}$

\section{Table 1: Passengers volume of air-travel by years}

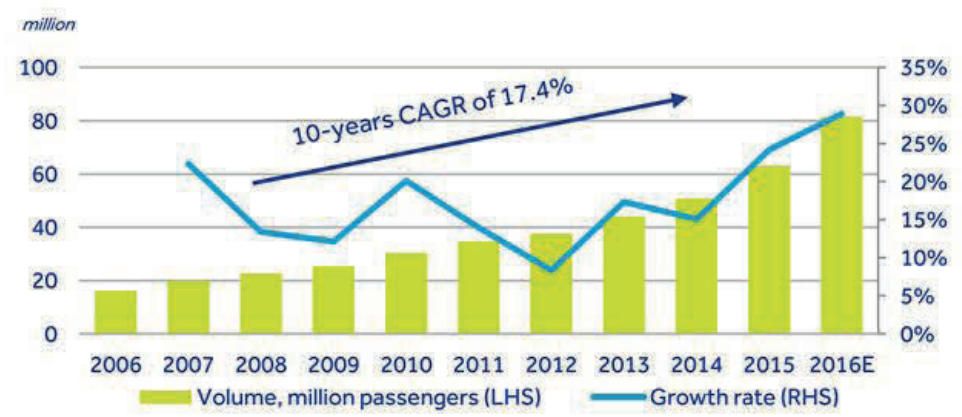

Source: AVC (2016)

ACV (2017), Annual Report 2017, p. 5

Ibid.

IATA (2016), IATA Forecasts Passenger Demand to Double Over 20 Years. Retrieved from http://www.iata.org/pressroom/pr/Pages/2016-10-18-02.aspx [accessed 12 August 2017] 
Table 2: CARG in the Asia-Pacific Region period 2005-2015

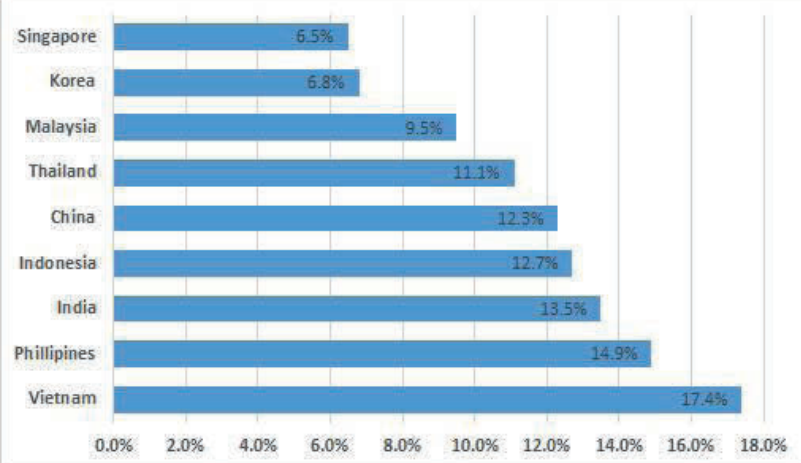

Source: Knoema (2017)

The development of the air-transport sector in Vietnam in the last 5 years is mainly attributed to the development of low-cost airlines. In 2011, the domestic aviation market was dominated by state-owned Vietnam Airlines (79.9\%) with Jetstar Pacific having a 12.3\% market share and others $7.6 \%{ }^{5}$. However, there have been substantial changes in recent years with the entry of Vietjet Air (Vietjet) into the market that initially had around 2.5 million passengers in 2012 but by 2016 had over 14 million passengers (a 4-year CAGR of 55.7\%). ${ }^{6}$ In 2016, Vietjet Air enjoyed a domestic market share of around $42 \%$, while those of Vietnam Airlines and Jetstar Pacific were $44 \%$ and $14 \%$ respectively. ${ }^{7}$

The competition in Vietnamese air-transportation is mainly between Vietnam Airlines and Vietjet. Amongst the domestic airlines currently operating in Vietnam, Jetstar Pacific and VASCO are connected to Vietnam Airlines ${ }^{8}$ and thus are not considered competitors to Vietnam Airlines. The confrontation of Vietjet and Vietnam Airlines generally represents the traditional vs. low cost model, and state-owned vs. private sector.

As to market equilibrium, the liberalization of the aviation and airport sectors have made it possible for newcomers to join the market; hence making life difficult for the former monopoly national flag carrier. In this regard, the role of the State as a regulator has become necessary - as fledging private sector enterprises are joining the formally monopolized aviation sector - to ensure fair terms of market access. In this new paradigm, it is essential that an

The other airline companies include Vietnam Air Services Company (VASCO), Air Mekong (ceased operation in 2013) and Vietnam Helicopter Corporation.

6 VOV (2017), 'Vietjet flights over 40 million passengers in 2016', The voice of Vietnam online. Retrieved from http://english.vov.vn/trade/vietjet-air-flies-over14-million-passengaers-in-2016-343565.vov [accessed 20 November 2017]

CAPA (2017), Vietnam domestic market: growth slows as Vietnam Airlines regains market share from VietJet Air.

Vietnam Airlines holds $68.5 \%$ equity interest in Jetstar Pacific and 51\% equity interests in VASCO. 
air transportation competition strategy be developed to ensure the efficient allocation of resources. Vietnam, being a country in transition, has to face precisely this issue.

\section{REMOVING THE STATE MONOPOLY IN THE AIR- TRANSPORT SECTOR}

Due to historical background, the liberalization in air-transport sector in Vietnam has been a long and complex process. Before the 1990s, Vietnam was politically and economically isolated from the rest of the world. The aviation industry was merely semi-military ${ }^{9}$, which was operated and managed by the Civil Aviation Administration of Vietnam (CAAV). ${ }^{10}$ The CAAV was assigned to act both as a government agency and as an enterprise engaging in aviation business. All air-transportation activities were centrally controlled in a tightly regulated system, engaging in only very limited commercial operations. The industry, overall, experienced losses from 1976 to 1989, even after taking into account the central government's subsidies to the industry. ${ }^{11}$ Deregulation in the air-transportation began in the 1990s, when the Government approved the establishment of Pacific Airlines in $1991^{12}$ and of Vietnam Airlines in $1993^{13}$. At that stage, although the government encouraged operating efficiency and profitability, the airlines were still tightly regulated by CAAV in every aspect of air services provision, market entry, route entry, frequency and pricing. In such a controlled environment, a real competition could hardly take place.

In 2000s, with pressures of global economic integration, the government decided to open up the civil aviation to private sector. ${ }^{14}$ The enactment of the Law of Civil Aviation in $2006^{15}$ provided a landmark in the deregulation and privatisation of the air-transportation sector.

$9 \quad$ Chi Nguyen (2001), A Strategy for The Vietnam Civil Aviation Administration to Promote USVietnam Bilateral Civil Aviation Agreement, MACD, Institute for Trade \& Diplomacy. Retrieved from http://www.commercialdiplomacy.org/pdf/ma_projects/nguyen_chi.pdf [accessed 20 February 2018]

10 Decision No. 666/TTg on establishment of Civil Aviation Administration of Vietnam (CAAV) dated 15 January 1956, CAAV was assigned with three main functions, including (i) state management, (ii) national defence, and (iii) commercialization of air transportation.

11 Supra note 10; see also Schermerhorn R. John Jr. (2000), Vietnam Airlines' CEO Dao Manh Nhuong on Strategic Leadership, Academy of Management Executive, Vol. 14 (4), pp. 16-19.

12 Pacific Airlines was established pursuant to the Decision No. 116/CT dated 13 April 1991 and Decision No. 188/CT dated 15 June 1991 of the Chairman of the Council of Ministers (equivalent to Prime Minister) and Decision No. 2355 QĐ/TCCB-LĐ dated 12 December 1990 and Decision No. 2016 QĐ/TCCB-LĐ dated 20 September 1992 of Ministry of Transportation and Post.

13 The Vietnam Airlines Corporations was established pursuant to the Decision No. 32/TTg dated 15 April 1993 of the Vietnamese Prime Minister.

14 Ministry of Transport (2007), Vietnam's Transport Sector and the WTO Accession.

15 Law No. 66/2006/QH11 on Civil Aviation of the National Assembly dated 29 June 2006. 
Noticeably, non-state-owned airlines were been granted rights to explore new flight routes in Vietnam. In addition, foreign investors were also allowed to invest into local airlines (with a limitation cap on ownership). This was the basis for Australian airline Quantas to acquire a 30\% stake in Pacific Airlines in 2007, ${ }^{16}$ which was restructured into a low-cost airline and renamed as Jetstar Pacific Airlines in May 2008. ${ }^{17}$ A number of other private airlines were also established to meet the development opportunities after Vietnam's successful accession to the WTO.

However, very few private start-up airlines were able to create a foothold in the air-transport industry. Arguably, market deregulation has been only partial because the State still sought to protect the national champion status of Vietnam Airlines through various regulatory means. Private airlines competing head-to-head with state-owned airlines must overcome the obstacle of "unfair treatment" by the CAAV. Vietnam Airlines has always received the best conditions for flight route and take-off and landing slots. As a matter of fact, the latter factor affects significantly the capability of private start-up airlines to compete with Vietnam Airlines in attracting customers. There was an incident in 2009, when over a week, nearly $90 \%$ passengers of Jetstar Pacific and Indochina Airlines cancelled their tickets and switched to the flights of Vietnam Airlines because of inconvenient flight schedules and flight delays (which were not entirely caused by the airlines).$^{18}$ In the subsequent two months, the two airlines could sell only $34 \%$ seats for all their flights despite the fact that they offered various discount programmes. ${ }^{19}$ The airlines faced serious problems in finding financial resources to cover their losses. Due to unresolved debts and a serious drop in customers, Indochina Airlines ceased operations in 2009 , after just one year in operation.

Obtaining sub-licenses for conducting air-transport services has been another serious challenge for private airlines. Pursuant to the law, after obtaining the Air Transport Business License (ATBL), airlines are required to get the Certificate of Aircraft Operator (CAO) from the CAAV to commence the air transport operations within 24 months. ${ }^{20}$ Failing to do so leads to the automatic revocation of the ATBL. The application process is not transparent and the CAAV has substantial discretion in imposing conditions on applicants. This leads to serious uncertainty and constitutes a

16 Francis L. (2012), Jetstar Pacific Completes Ownership Change to Vietnam Airlines, Quantas, Aviation Week Intelligence Network, 22 February 2012.

Ibid.

Mai Lan (2017), 'How fierce is the competition between traditional airlines and Budget airlines? '(Cạnh tranh giưa hàng không truyền thống và hàng không giá rẻ đã khốc liệt như thế nào?), Tri Thuc Tre, (22 June 2017).

Ibid.

Article 17, Decree No. 76/2007/ND-CP of the Government on Air Transportation Business and General Aviation dated 9 May 2007. 
serious barrier to market entry. Both Vietjet and Indochina Airlines almost had their ATBL revoked due to the late issuance of the CAO by the CAAV. In addition to this issue, private airlines have also faced problems in opening flight routes. They must undergo complex administrative procedures to get approval from CAAV for entry to and exit from a route, and for an increase in the number of flights on any route. These issues, however, were not of concern to the state-owned airlines; contrary to the treatment of private airlines, the CAAV showed flexibility in allowing state-owned airlines to open new flight route faster than private competitors and imposing minimal additional costs.

There are, however, indicators that the CAAV has gradually loosened the criteria for entry and exit in the domestic market since 2012. Airlines with better safety records, higher on-time performance rates and service quality appraisals have been awarded priority in opening new routes and expanding frequencies. In addition, with the aim to develop hub-airports in major cities like Hanoi, Ho Chi Minh City, Hai Phong, Da Nang, and Can Tho, the opening of routes to these cities has been encouraged. ${ }^{21}$

Price regulations have been another concern for private competitors in the air-transport market. As analysed above, private airlines in Vietnam are positioned as low-cost-carriers and therefore, "lowering the price" is considered a central element in their business strategy. The expansion of Vietjet in the last five years was mainly based on its savvy marketing and low fares. In 2017, the CAAV attempted to regulate the price of passenger transport services on domestic flights by setting a framework for ceiling and floor prices for airfares, following requests from state-owned Vietnam Airlines and Jetstar Pacific. The two airlines argued that a floor price should be established because airlines in the market were continually reducing ticket prices (even selling below costs) to attract passengers, and this could affect the normal business performance and sustainable development of the aviation industry. ${ }^{22}$

They proposed CAAV to calculate the floor price by taking the direct cost of the flight as the basis for setting the floor price and the expected floor price for the five major flight routes to range from 29\% to $34 \%$ of the ceiling price. ${ }^{23}$ However, the CAAV's plan was strongly criticised by various parties in the society. It was argued that the responsibility of the State is to

\footnotetext{
$21 \quad$ Decision No. 318/QD-TTg of Prime Minister Approving the Planning on the Development of Transport Services Within the Period to the Year 2020 and Orientations to the Year 2030 dated 04 March2014.

22 Ha My (2017), 'Fixing the floor price of airfares: Vietjet opposes, Jetstar and Vietnam Airlines support' (Áp giá sàn vé máy bay: Vietjet phản đối, Jetstar và Vietnam Airlines ủng hộ), Tri Thuc Tre, 13 March 2017.

$23 \quad$ Ibid.
} 
ensure a fair competitive environment and supervise the quality of products provided in the market, not to decide on the sales price policy of airlines. Price competition by airlines is beneficial for customers in Vietnam (unless the action is proven to be predatory pricing). In other words, the fixing of floor price in accordance with the proposal of Vietnam Airlines and Jetstar Pacific was clearly anti-competitive and obviously caused consumer welfare loss by attempting to raise baseline prices, reducing consumer choice and access to air-transportation services and thereby distorting the market.

Thus, the proposed CAAV measures may be considered to be prohibited conduct by State administrative bodies that restrain competition in the market in breach of Article 6 of the Competition Law. After discussion with various opinion groups and consultation with competition authorities, the CAAV decided to abandon its plan of regulating airfares. The impact of the general competition law in policy making was important here to prevent the adoption of an obviously anticompetitive regulatory restraint on competition and will hopefully be an important influence on the further development of an open air-transport market in Vietnam.

Overall, the "protective fortress" around the airline industry within the ideology of a centrally planned economy in Vietnam has been gradually removed. Despite a general policy to support the national champion status of Vietnam Airlines, the CAAV has started to pay some respect to the market economy principles and thus, refrain from unreasonable interference to prevent competition in the market. The state-owned airlines' consolidations under Vietnam Airlines have given flag air-carriers greater opportunity to coordinate schedules and prices, reduce their costs and improve economies of scale. However, low-cost-carriers such as Vietjet have also facilitated conditions to grow the airline market generally and also to take market share from Vietnam Airlines Group. It is believed that policy makers now agree that maintaining competition in the air-transport market is positive as it helps to improve the overall efficiency of domestic air-carriers, which is of great importance to enable the national champions to compete against foreign airlines in the era of globalisation. The implementation of the ASEAN Single Aviation Market (ASAM) has forced the Vietnamese government to remove restrictions on third, fourth, and fifth airspace freedoms for airlines based in ASEAN member states, which certainly increases competition in the air-transport market. In this context, airlines with efficient cost structures will be better able to cope with volatility in the market. The development of ASEAN open skies policy under ASAM is also seen as an important opportunity for strong domestic airlines to become regional players. ${ }^{24}$

$24 \quad$ Supra note 21. 


\section{IMPACT OF AIRPORT AND OTHER AIR-SUPPORT SERVICES ON AIR-TRANSPORT COMPETITION}

In assessing competition in the air-transport industry, it is essential to analyse airport and aircraft-supporting services too because of their symbiotic relationship. The operation of the civil airlines depends on the air-transport infrastructure services - comprising of airport services (terminal services, transfer of waiting-passengers, luggage-handling, security services, etc.) and air-support services (fuel supply services, aircraft maintenance, land side service, airside services, surface access and air navigational services). These ancillary support services are a vital input market for air-transport services and, therefore, affect directly the competition in the air-transport market. Any imperfections or deficiencies in any one of these inputs may affect the entire operational efficiency and competition of the air-transport market.

In Vietnam, like in most countries in the world, the bulk of airtransport infrastructure has been created by the public sector. To date, this market has not yet been liberalized by the State due to security and capital intensive requirements. Since the State owns and operates the entire ecosystem (airports, airport facilities, aircraft fuel supply services) stateowned enterprises operating these services have both the opportunity and the economic and political incentives to hamper competition and so hinder improvements in service quality and reduction of airfares.

The anti-competitive nature of the relationships of enterprises operating in air-transport and air-support markets can be explained by the concept of margin squeeze. It is argued that margin squeeze may occur when an incumbent operates in both the upstream and downstream markets. ${ }^{25}$ Where a downstream rival requires access to the upstream market in order to compete with the incumbent in the downstream market, the incumbent will seek to raise its rivals' costs in the downstream market by charging a high access price to the upstream market, so as to stifle competition. ${ }^{26}$ Khemani Shyam has commented that raising rivals' costs may be less costly than predatory pricing as a means of excluding competitors from the market, because it may not require a direct reduction in profits for the dominant firm. ${ }^{27}$ However, a margin squeeze qualifies as a standalone abuse of dominance by focusing on the spread of prices, and not on the lawfulness of each price level. There are two prerequisites for a squeeze margin strategy: (i) the subject enterprise must be active on both upstream and downstream markets; and (ii) the

25 Jullien B. (2013), 'Patrick Reyand Claudia Saavedra', The Economics of Margin Squeeze, IDEI Report, 10/2013, p. 4.

Ibid.

27 Khemani, R. S. et al (1998), Framework for the design and implementation of competition law and policy, World Bank, p. 78. 
subject enterprise or its affiliate(s) must have a monopoly or dominant market position in the upstream market. Only when these two conditions are met, the enterprise will be able to discriminate against its competitor(s) in downstream market.

The correlation between the air-transport and airport/aircraft-support represents the relationship of upstream and downstream markets. Airport and air-support services supply services to airlines, and as such represents the upstream market. The assessment of market power of airports has to take these interdependencies into account, and contain an analysis of the economic interaction between the downstream air-transport markets and the impact of this interaction on the demand for airport services upstream. ${ }^{28}$

Since the upstream market is yet to be privatised, all airlines must use the services provided by state-owned enterprises. Although, formally, the airport, aircraft fuel suppliers, landside service suppliers, surface access suppliers are independent legal entities, it is reasonable to assume that their affiliation with common state-ownership can affect their business relationships. The airport and air-support service providers might be tempted to give priority to the fellow state-owned airlines over private competitors. As air-support services are an essential input of air-transportation services, any changes in the price or quality of air-support services will inevitably affect the cost structure and quality of the services of airlines. Accordingly, when they apply lower prices or give preferential trading terms or better quality of service to state-owned airlines compared to private competitors, it causes differences in the cost of the provision of private airlines' services and in their quality of their customer services. Given the fact that all private airlines in Vietnam operate in lowcost segment, the price of airfares plays critical role in their competitive strategy. Thus, if airlines support service providers raise service price(s) but the private airlines cannot pass-on that increase in cost to consumers, they will soon be squeezed in terms of profitability and/or sales.

The cost of production of air-transport services depends, to a significant extent, on the costs of upstream air-transport infrastructure services; and quality of airline services can be adversely affected by matters such as unfavourable landing slots, inefficient security or baggage handling services. Thus, simply opening one part of the market will not necessarily result in a more competitive sector as a whole. The entire interlocking market structure has to be changed to achieve a more competitive outcome. Simply allowing new airlines into the market is insufficient to achieve an optimal competitive outcome.

$28 \quad$ Bilotkach V. and Polk A. (2013), The Assessment of Market Power of Hub Airports, Transport Policy, Issue 29, pp. 29-37. 


\section{Vinapco case}

The Vinapco case is one of the milestone cases relating to abuse of monopoly power by state-owned enterprises in the aviation industry in Vietnam. Vinapco is a state-owned company established in 1993 to supply aviation fuel to Vietnam Airlines and has maintained a monopoly in the supply of fuel to all other airlines operating in Vietnam since then. On 31 September 2007, Vinapco and Pacific Airlines signed a contract for the supply of aircraft fuel for 2008. The pumping fee for one ton of fuel was set at VND 593,000 (around US\$32.9). On 12 March 2008, Vinapco unilaterally attempted to increase the pumping fee to 750,000 VND/ton (around US\$41.6). ${ }^{29}$ Vinapco argued that price increase was necessary to respond to global price fluctuations. Pacific Airlines did not agree with this new price because it believed that Vinapco had unfairly raised the price. The reason for this was that the fuel price that Vinapco charged Vietnam Airlines, a state-owned competitor airline, was unchanged. When Pacific Airlines refused to accept the fee increase, Vinapco cut off its supplies on 1 April 2008. ${ }^{30}$ The action of Vinapco caused delays for some 30 flights of Pacific Airlines and affected more than 5,000 passengers. ${ }^{31}$ Vinapco was quickly ordered by the Minister of Transport to continue supplying fuel to Pacific Airlines, despite the dispute over the fuel price.

In terms of strategic competition, this incident is a typical case of margin squeeze. Accordingly, the aircraft fuel supply market was under the monopoly of Vinapco. Its customers were domestic airlines -Vietnam Airlines and Pacific Airlines. Vinapco and Vietnam Airlines were both wholly state-owned enterprises. Though the enterprises were legally distinct they could be considered as being a single economic entity due to the fact that both of them were owned by the same proprietor - the State. As a result, the State was active in both the upstream aviation fuel supply market and the downstream air-services market and had absolute control of the upstream fuel supply market. Consequently, Vicapco's actions in setting a discriminatory price for the supply of fuel constituted an effective margin squeeze on its downstream competitor, Pacific Airlines.

The essence of a low cost airline strategy is to cut back on added value services to cut costs, so customers will be able to buy tickets at lower prices than the price of traditional full-service airlines. Specifically, when using lowcost airlines, passengers choose to trade off a reduced utility - superior service quality - compared to that of traditional full-service airlines. Thus, if the price

\footnotetext{
29 Decision No. 11/QĐ-HĐXL dated 14 April 2009 regarding the settlement the incident that Vinapco ceased to provide fuel for PA.

Ibid.

Ibid.
} 
difference between low-cost and traditional airlines is negligible, passengers will not be motivated to choose low-cost airlines over traditional ones.

After the Vinapco case, the government ordered the Ministry of Transport (MOT) to adjust the competition conditions in the air-service supply market. The MOT began to dismantle the Vinapco monopoly of aircraft fuel supply in Vietnam by assigning supply rights to various state-owned enterprises. Subsequently, those enterprises were converted into joint-stock companies, but the State still remains the controlling shareholder in each of them. The change of policy has been considered as an important move to create competition in one of the upstream air-support services market. However, it has yet to remove the effective State monopoly in the upstream fuel supply market. It is suggested that as long as ownership linkages remain in the air-transport and air-support service markets, the possibility of market squeeze distortions cannot be fully eliminated.

The administrative control over the price of air-support services still remains in Vietnam, and may also cause competition problems. For example, the MOT would, from time to time, adopt price brackets for air-support services in the name of maintaining the stability and predictability of price structure in the market. Recently, in 2016, it introduced Decision No. 3065/ QD-BGTVT promulgating the price bracket of aircraft refuelling services ${ }^{32}$ and Decision No. 2345/ QD-BGTVT promulgating the price brackets of certain upstream air support services in domestic airports in $2017 .{ }^{33}$

MOT officials consider such measures as means to address the "margin squeeze" issue and prevent the possibility of cases such as the Vinapco case to happen again. They reasoned that, under this scheme, private domestic air-transport enterprises are able to access and/or use support services for flight operations similarly as state-owned airlines. Hence, this approach is irrational from an economic efficiency perspective. Arguably, even if the MOT's objective is to support the competition in the air-transport market, the measures of fixing prices are fundamentally flawed as they substitute administrative diktat for market competition. To prevent abusive practices by enterprises providing air-support services, it is essential to create open conditions for market entry. The State should re-evaluate the rationale for its ownership of all enterprises in the sector in order to determine whether a deregulation and/or privatisation strategy in this sector may provide a better economic outcome. Accordingly, the ultimate purpose of state ownership

32 Decision No. 3065/QD-BGTVT of Ministry of Transport promulgating the frame for charges for petrol and oil refueling services and services using infrastructures for underground charging systems to supply fuel at airports and airfields, dated 30 September 2016.

33 Decision No. 2345/ QD-BGTVT of Ministry of Transport promulgating price rates, price lists of a number of aviation services at Vietnamese airports. 
of enterprises should be to maximise value for society, through an efficient allocation of resources, but this objective may not be attainable in this sector with absolute state control..$^{34}$ Due to industry particularities, many diverse issues must be taken into account when assessing which policies should be perused to improve the allocation of resources and to foster growth and greater efficiency. Questions such as upstream and downstream markets interaction, airport congestion, and sector efficiency must be considered, along with the compatibility of policy choices with competition law. The Vietnam Competition Authority, when assessing the issue of the State management of the aviation industry, generally advocates the position taken in Article 4.1 of the Competition Law, which is the freedom of competition within the framework of the law and that provides that the State shall protect the right to compete lawfully, irrespective of the ownership of enterprises.

Controlling the market forces by way of administrative fiat is not a basis to guarantee market-based development in the air-transport sector. Hence, any anticompetitive administrative action in the air-transport supply chain will have a negative impact on the development of air transport competitive market as a whole. Thus, it is suggested that the success of deregulation of air-transport sector vitally depends on the deregulation of upstream airport and air-supply service sector. To ensure the effective ecosystem for the aviation sector, it is essential that MOT officials understand and promote the application of pro-competitive policies and understand how the competition law applies to its policy choices.

\section{CONCLUSION}

Given the achievements in the development of the air-transport industry in last decade, the experience of Vietnam is an interesting case study for many similar countries in transition. The deregulation of the airtransport sector in 2005 has allowed the participation of the private sector in the air transport industry, but competitive conditions between private and national state-owned airlines are not entirely fair given the condition of upstream air-support services markets and the interference by state sectoral regulators imposing anti-competitive rules in those upstream markets.

The prerequisite for economic efficiency in the air-transport sector is that the State must ensure equality in the operation of the air transport supply chain. Competition is crucial to any liberalization process, where regulatory authorities should retreat and economic agents replace them in

OECD (2015), OECD Guidelines on Corporate Governance of State-Owned Enterprises, p. 17. Retrieved from http://www.bicg.eu/wp-content/uploads/2017/07/OECD-2015.pdf [accessed 10 March 2018]. 
both the airline industry as well as in the upstream supply markets. ${ }^{35}$ Only free and open markets, based on competitive neutrality, will force enterprises to compete based on their merits. Competition, by its nature, implies rivalry but within the limits set by competition law. The role for state sectoral regulators should not be to influence the market outcomes (in terms of number of players, price and quantities), but - as a referee - to preserve the contestability of air transport markets in the light of the current economic conditions. In this way competition-distorting strategies by linked operators (leading to the exploitation of market power in terms of output restrictions and price increases) will be reduced, while efficiency-promoting strategies (including those aiming at excluding less efficient competitors) would be maximized, with the final result of increasing consumer welfare. ${ }^{36}$

\section{References}

[1] ACV (2017), Annual Report 2017, p. 5

[2] Benacchio M. (2008), Consolidation in the air transport sector and antitrust enforcement in Europe, EJTIR, 8, No. 2, pp. 91-116

[3] Bilotkach V. and Polk A. (2013), The Assessment of Market Power of Hub Airports, Transport Policy, Issue 29, pp. 29-37

[4] Button K. (2008), The Impacts of Globalisation on International Air Transport Activity: Past trends and future perspectives, Conference Paper, OECD/ITF Global Forum on Transport and Environment in a Globalising World, held 10-12 November 2008 in Guadalajara, Mexico, pp. 6-7

[5] CAPA (2017), Vietnam domestic market: growth slows as Vietnam Airlines regains market share from VietJet Air

[6] Chi Nguyen (2001), A Strategy for The Vietnam Civil Aviation Administration to Promote US-Vietnam Bilateral Civil Aviation Agreement, MACD, Institute for Trade \& Diplomacy. Retrieved from http:// www.commercialdiplomacy.org/pdf/ma_projects/nguyen_chi.pdf [accessed 20 February 2018]

[7] Francis L. (2012), Jetstar Pacific Completes Ownership Change to Vietnam Airlines, Quantas, Aviation Week Intelligence Network, 22 February 2012

[8] Ha My (2017), 'Fixing the floor price of airfares: Vietjet opposes, Jetstar and Vietnam Airlines support' (Áp giá sàn vé máy bay: Vietjet phản đối, Jetstar và Vietnam Airlines ủng hộ), Tri Thuc Tre, 13 March 2017

[9] IATA (2016), IATA Forecasts Passenger Demand to Double Over 20 Years. Retrieved from http:// www.iata.org/pressroom/pr/Pages/2016-10-18-02.aspx [accessed 12 August 2017]

[10] Khemani, R. S. et al (1998), Framework for the design and implementation of competition law and policy, World Bank, p. 78

[11] Mai Lan (2017), 'How fierce is the competition between traditional airlines and Budget airlines? '(Cạnh tranh giữa hàng không truyền thống và hàng không giá rẻ đã khốc liệt như thế nào?), Tri Thuc Tre, (22 June 2017)

[12] Ministry of Transport (2007), Vietnam's Transport Sector and the WTO Accession

[13] Jullien B. (2013), 'Patrick Reyand Claudia Saavedra', The Economics of Margin Squeeze, IDEI Report, 10/2013, p. 4.

[14] OECD (2015), OECD Guidelines on Corporate Governance of State-Owned Enterprises, p. 17. Retrieved from http://www.bicg.eu/wp-content/uploads/2017/07/OECD-2015.pdf [accessed 10 March 2018]

[15] Schermerhorn R. John Jr. (2000), Vietnam Airlines' CEO Dao Manh Nhuong on Strategic Leadership, Academy of Management Executive, Vol. 14 (4), pp. 16-19

[16] VOV (2017), 'Vietjet flights over 40 million passengers in 2016', The voice of Vietnam online. Retrieved from http://english.vov.vn/trade/vietjet-air-flies-over-14million-passengaers-in-2016-343565.vov [accessed 20 November 2017]

\footnotetext{
35 Benacchio M. (2008), Consolidation in the air transport sector and antitrust enforcement in Europe, EJTIR, 8, No. 2, pp. 91-116.

$36 \quad$ Ibid.
} 